\title{
REPORT ON TWO SPECIES OF DIGENEA FROM MARINE FISHES IN BRAZIL
}

\author{
FERNANDES, B. M. M., ${ }^{1}$ PINTO, R. M. ${ }^{2}$ and COHEN, S. C. ${ }^{1}$ \\ ${ }^{1}$ Laboratório de Helmintos Parasitos de Peixes, Departamento de Helmintologia, Instituto Oswaldo Cruz, \\ Av. Brasil, 4365, CEP 21045-900, Rio de Janeiro, RJ, Brazil \\ ${ }^{2}$ Laboratório de Helmintos Parasitos de Vertebrados, Departamento de Helmintologia, Instituto Oswaldo Cruz, \\ Av. Brasil, 4365, CEP 21045-900, Rio de Janeiro, RJ, Brazil \\ Correspondence to: Berenice M. M. Fernandes, Laboratório de Helmintos Parasitos de Peixes, Departamento de \\ Helmintologia, Instituto Oswaldo Cruz, Av. Brasil, 4365, CEP 21045-900, Rio de Janeiro, RJ, Brazil, \\ e-mail: berenice@ioc.fiocruz.br \\ Received August 6, 2001 - Accepted October 8, 2001 - Distributed August 31, 2002
}

(With 2 figures)

\begin{abstract}
Two species of Digenea were recorded for the first time in South America and in new hosts: Acanthostomum spiniceps (Looss, 1896) (Cryptogonimidae) was reported from Astroscopus sexspinosus (Steindachner, 1877) (Uranoscopidae) and Diplomonorchis sphaerovarium Nahhas \& Cable, 1964 (Monorchiidae) from Ophichthus gomesi (Castelnau, 1855) (Ophichthidae). From the latter, Heliconema heliconema Travassos, 1919 (Nematoda, Physalopteridae), was also recovered representing also a new host for this nematode species.
\end{abstract}

Key words: Digenea, marine fishes, Brazil.

\section{RESUMO}

\section{Duas espécies de Digenea de peixes marinhos no Brasil}

Duas espécies de Digenea foram registradas pela primeira vez na América do Sul e em novos hospedeiros: Acanthostomum spiniceps (Looss, 1896) (Cryptogonimidae) foi coletado de Astroscopus sexspinosus (Steindachner, 1877) (Uranoscopidae) e Diplomonorchis sphaerovarium Nahhas \& Cable, 1964 (Monorchiidae), de Ophichthus gomesi (Castelnau, 1855) (Ophichthidae). Deste último hospedeiro, uma espécie de Nematoda Heliconema heliconema Travassos, 1919 (Physalopteridae) foi coletada, representando também um novo hospedeiro para este nematóide.

Palavras-chave: Digenea, peixes marinhos, Brasil.

\section{INTRODUCTION}

During the course of a study on fish parasites from the coast of Rio de Janeiro State, two species of Digenea, Acanthostomum spiniceps and Diplomonorchis sphaerovarium, and a species of nematode, Heliconema heliconema, were recovered from new hosts. These digenean species are reported for the first time in South America.

\section{MATERIALS AND METHODS}

The helminths were recovered from fishes from Copacabana and Urca beaches, Rio de Janeiro State, Brazil, and were fixed under coverslip pressure in AFA (alcohol, formalin, acetic acid), stained in alcoholic chlorydric carmine of Langeron, dehydrated in ethyl alcohol, cleared in beechwood creosote and mounted in Canada balsam. The illustrations were 
made with the aid of a Leitz drawing tube, and the measurements are in micrometers unless otherwise indicated. Material was deposited in the "Coleção Helmintológica do Instituto Oswaldo Cruz (CHIOC)". Considering that these helminths are well described, we present herein only the main measurements and figures of the two digenean species studied.

\section{RESULTS AND REMARKS}

Acanthostomum spiniceps (Looss, 1896) Looss, 1899 (Cryptogonimidae)

Host: Astroscopus sexspinosus (Steindachner, 1877) (Uranoscopidae).

Site: intestine.

Locality: Copacabana beach, Rio de Janeiro State, Brazil.

Intensity of infection: 1 out of the 10 fish specimens examined was parasitized by 1 Digenea.
Voucher specimens deposited: CHIOC n. 34.555.

Measurements based on one specimen. Body $3.37 \times 0.57 \mathrm{~mm}$; oral sucker $318 \times 270$, surrounded by 27 spines in a row; pre-pharynx 67 long; pharynx $138 \times 135$; oesophagus 30 ; ventral sucker $150 \times 138$; sucker width ratio 1:0.5; anterior testis 285 in diameter and posterior testis $315 \times 281$; ovary $243 \times 187$; eggs $35-42 \times 18$. Up to the present moment, the genus Acanthostomum has been referred to only in freshwater fishes and reptiles. This is the first report of a member belonging to this genus in a marine fish.

This species was originally described from Bagrus bayad (Ariidae) from Egypt and has also been reported from the type-host and locality by Fischtal \& Kuntz (1963); Imam et al. (1991) and Soliman \& El-Damarany (1995). Also in Egypt, A. spiniceps was recorded from Bagrus filamentosus (Ariidae) by Tadros et al. (1978) and from Morone labrax (Percichthyidae) by El-Shahawi \& Al-Bassel (1992).

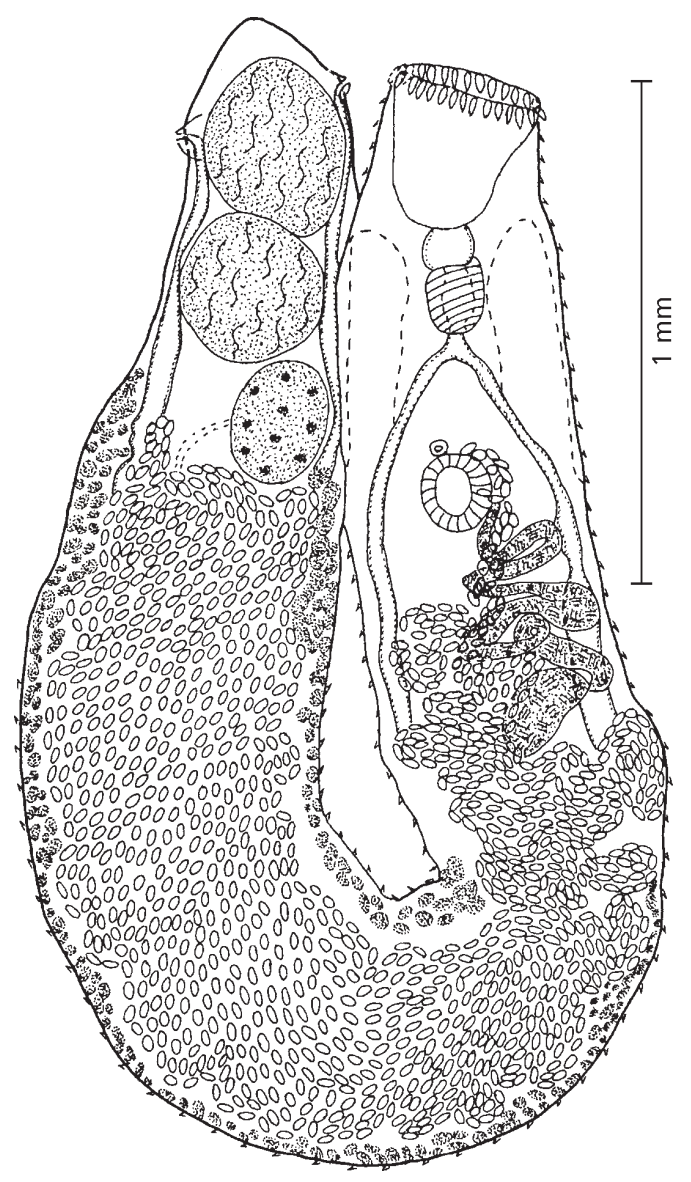

Fig. 1 - Acanthostomum spiniceps. Total, ventral view. 
This species was also recovered by Dollfus (1932) from Bagrus filamentosus (Ariidae) and Chrysichthys furcatus (Ariidae) from Mali and by Pogoreltseva (1952) from Mullus barbatus ponticus (Mullidae) from the Black Sea.

Moravec (1976) redescribed A. spiniceps from the type host and from Bagrus docmac (Ariidae) from the type locality, based on 41 specimens, observing great morphometric variability.

The present study was based on a single specimen, which is closely related to those studied by Fischthal \& Kuntz (1963) regarding to the body size, although presenting larger eggs. In relation to the number of circumoral spines, our specimen is similar to the material studied by Moravec (1976), with 27 spines.

Diplomonorchis sphaerovarium Nahhas \& Cable, 1964 (Monorchiidae)

Host: Ophichthus gomesi (Castelnau, 1855) (Ophichthidae).

Site: intestine.

Locality: Urca beach, Rio de Janeiro State, Brazil.
Intensity of infection: 4 out of the 21 fish specimens examined were parasitized by 1 to 4 Digenea.

Voucher specimens deposited: CHIOC $n$. 33.121 a-e.

Measurements based on 5 specimens. Body $1.84-2.95 \mathrm{~mm}$ long by $0.45-0.69 \mathrm{~mm}$ wide; oral sucker 150-176 x 165-195; prepharynx 21-22 long; pharynx 71-86 x 78-105; oesophagus 56-131 long; ventral sucker $116-142 \times 108-146$; sucker width ratio 1:0.5-0.7; cirrus sac 401-494 x 111-166; seminal vesicle $187-337$ x 105-157; cirrus 93-177 x 35-55; testes 168 296 × 90-221; ovary 123-168 x 93-157; metraterm sac 255-315 x 105-150; eggs 21-28 x 14-19.

Up to this date, the genus Diplomonorchis Hopkins, 1941, was represented in Brazil by three species: D. catarinensis from the intestine and pyloric caeca of Micropogonias furnieri (Sciaenidae) (Amato, 1982), D. floridensis Nahhas \& Powell, 1965 from the intestine of Symphorus sp. (Cynoglossidae) (Wallet \& Kohn, 1987) and D. leiostomi Hopkins, 1941 from the intestine of Haemulon sciurus (Pomadasyidae) (Kohn et al., 1982) and Boridia grossidens (Sparidae) (Fernandes et al., 1985).

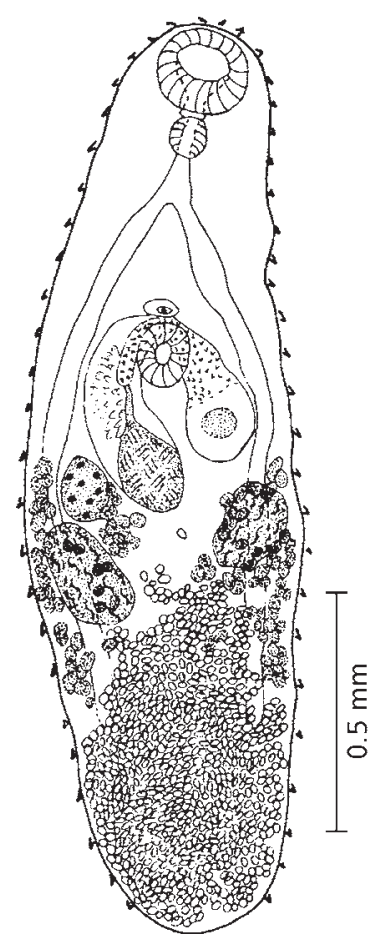

Fig. 2 - Diplomonorchis sphaerovarium. Total, ventral view. Original figures. 
Diplomonorchis sphaerovarium was decribed from the intestine of Spheroides testudineus (Tetraodontidae) from Jamaica, and this is the first report of this species since its original description, representing also the first report of this species in South America and in a new host. The specimens presently studied are similar to those reported in the original description, being slightly longer.

\section{Heliconema heliconema Travassos, 1919}

Adult and larval forms of $H$. heliconema were also recovered from two out of the 21 specimens of $O$. gomesi examined. From Brazil this species was originally described by Travassos (1919) from Echidina catenata (Muraenidae) from Trindade Island, and has been reported by Guimarães et al. (1976) from Ophichthus ophis (Ophichthidae) from Bahia State. It was also reported from Pakistan by Khan \& Begum (1971) parasitizing Muraenesox cinereus (Muraenesocidae). The present data on $H$. heliconema are in agreement with those previously stated and no additional comments are required, except for the new host record, Ophichthus gomesi.

\section{REFERENCES}

AMATO, J. F. R., 1982, Digenetic trematodes of percoid fishes of Florianópolis, Southern Brazil - Monorchiidae, with the description of two new species. Rev. Bras. Biol., 42: 701-719.

DOLLFUS, R. P., 1932, Mission Saharienne AugiérasDraper, 1927-1928. Trématodes de mamifères, oiseaux et poissons. Bull. Mus. Nat. Hist., Paris, Sér. 2, 4: 555563.

EL-SHAHAWI, G. A. Z. \& AL-BASSEL, D. A., 1992, A general survey of the helminth parasites infecting common fishes in some inland water in Egypt. Proc. Zool. Soc. A. R. Egypt, 23: 227-241.

FERNANDES, B. M. M., KOHN, A. \& PINTO, R. M., 1985, Aspidogastrid and digenetic trematodes parasites of marine fishes of the coast of Rio de Janeiro State, Brazil. Rev. Brasil. Biol., 45: 109-116.
FISCHTAL, J. H. \& KUNTZ, R. E., 1963, Trematode parasites of fishes from Egypt. Part V. Annotated record of some previously described forms. J. Parasitol, 49: 9198.

GUIMARÃES, J. F., CRISTÓFARO, R. \& RODRIGUES, H. O., 1976, Alguns nematódeos de peixes de Salvador, Bahia. Atas Soc. Biol. Rio de Janeiro, 18: 21-23.

IMAM, E. A. E., EL-ASKALANY, M. A. \& RASHAD, S. M., 1991, Studies on helminths parasites of Synodontis schall and Bagrus bayad from Beni-Suef water resources. Assiut. Vet. Med. J., 24: 137-152.

KHAN, D. \& BEGUM, A., 1971, Helminth parasites of fishes from West Pakistan. I. Nematodes. Bull. Dep. Zool. Univ. Punjab, 5: 1-22.

KOHN, A., MACEDO, B. \& FERNANDES, B. M. M., 1982, About some trematodes parasites of Haemulon sciurus (Shaw, 1803). Mem. Inst. Oswaldo Cruz, 77: 153-157.

MORAVEC, F., 1976, On two Acanthostomatid trematodes, Acanthostomum spiniceps (Looss, 1896) and $A$. absconditum (Looss, 1901), from African bragrid fishes. Folia Parasitologica, 23: 201-206.

POGORELTSEVA, T. P., 1952, New trematodes of Black Sea fishes. Trudy Karadagsk Biol. Stantsii NA Ukr. SSR, 12: 34-55.

SOLIMAN, F. M. \& EL-DAMARANY, M., 1995, Prevalence of helminth infection among some Nile fishes in relation to some biological aspects. J. Egypt. German Soc. Zool., 16: $253-275$.

TADROS, G., ISKANDAR, A. R. \& WASSEF, N. A., 1978, On some intestinal trematodes from the Nile and Red Sea fishes with a histopathological study of their habitat. $J$. Egypt. Soc. Parasit., 8: 383-392.

TRAVASSOS, L., 1919, Informações sobre o material helminthologico colleccionado na Ilha da Trindade em 1916. Arch. Mus. Nac. Rio de Janeiro, 22: 161-167.

WALLET, M. \& KOHN, A., 1987, Trematodes parasites de poissons marins du littoral de Rio de Janeiro, Brasil. Mem. Inst. Oswaldo Cruz, 82: 21-27. 